\title{
EFFECT OF ACUTE CLINICAL STRESS ON THE LEVELS OF HEXOSAMINE IN SERUM AND ITS EXCRETION IN URINE
}

\author{
BY NORMAN F. BOAS, 1 ALFRED J. BOLLET, AND JOSEPH J. BUNIM \\ (From the National Institute of Arthritis and Metabolic Diseases, National Institutes of Health, \\ Public Health Service, U. S. Department of Health, Education and Welfare, \\ Bethesda, Md.)
}

(Submitted for publication November 19, 1954; accepted December 29, 1954

The total serum hexosamine ${ }^{2}$ level is elevated in many unrelated chronic diseases $(1,2)$, and in experimental animals following acute injury (3, 4). It is not clear whether this elevation is due to increased production, diminished utilization or merely a shift of tissue hexosamines into the circulation. Since the activity of the adrenal glands is increased in many of these conditions of acute and chronic stress, the role of the adrenal cortex in sontrclling serum hexosamine levels has been studied. During the course of these studies, it was noted that normal urine contained relatively large amounts of hexosamine, which also increased during conditions of stress. The excretion of hexosamine in the urine in a variety of clinical situations has been measured, therefore, for the purpose of defining factors which alter the rate of its excretion and of correlating excretion levels with changes in serum hexosamine.

An ion exchange technique has been applied to urine hydrolysates for the purpose of separating hexosamines from the many chromogens in urine which interfere with the colorimetric determination of hexosamine (5). Previously reported studies on urinary hexosamine have not taken this into account and consequently report erroneously high values $(6,7)$.

\section{METHODS}

All patients selected for urinary hexosamine determinations were free of demonstrable renal disease as indicated by their clinical histories, by blood urea nitrogen determinations, and by routine examination of the urine for cells, casts, and protein. All urines were refrigerated

\footnotetext{
1 Present address: Research Division, Department of Laboratories, Norwalk Hospital, Norwalk, Conn.

2 The naturally occurring hexosamines are glucosamine and galactosamine. The methods used here do not distinguish between these two amino sugars.
}

( $4^{\circ}$ C.) without preservatives until the completion of each collection, and then frozen until ready for analysis.

For the determination of hexosamine an aliquot of urine $(1 \mathrm{ml}$.) or plasma $(0.1 \mathrm{ml}$.) was hydrolyzed in $2 \mathrm{~N}$ hydrochloric acid for 15 hours at $100^{\circ} \mathrm{C}$. After dilution and filtration, the hexosamine was isolated from the hydrolysate on Dowex -50 and determined by a modification of the method of Elson and Morgan (5). All urine samples and the serum from the case of gout were analyzed by the above method. The remaining serum hexosamine determinations were carried out by a previous modification of the method of Elson and Morgan (2). In this report, serum hexosamine values are expressed as mg. per cent change from an observed control value in the same individual. Where control values were unattainable such as in the cases of myocardial infarction, the hexosamine levels are expressed as milligrams per cent change from the mean hexosamine level observed in a series of normal individuals (107 mg. per cent) (2).

Electrophoresis of serum proteins was carried out on Whatman No. 1 filter paper sheets using a horizontal apparatus (Arthus H. Thomas, Co.). For the separation of proteins, 0.01 to $0.02 \mathrm{ml}$. of plasma were applied on a $25 \mathrm{~mm}$. line. For hexosamine studies $0.1 \mathrm{ml}$. was applied to a $150 \mathrm{ml}$. line. Separations were carried out in $\mathrm{pH} 8.6$ veronal buffer (ionic strength 0.06 ) at room temperature and constant current $(10 \mathrm{~mA})$ for five to six hours. The voltage generally fell from 250 to $190 \mathrm{~V}$ during the separation. At the completion of a separation the paper was dried in an oven at $110^{\circ} \mathrm{C}$. for 20 minutes, stained for 7 minutes in an alcoholic solution of 0.1 per cent bromphenol blue saturated with mercuric chloride (8), rinsed in tap water and dried again in an oven at $110^{\circ} \mathrm{C}$. For an analysis of the protein components, optical density of a dyed strip was read at $600 \mathrm{~m} \mu$ in a Beckman Spectrophotometer (Model DU) by the use of a specially constructed strip holder. A protein distribution curve was obtained by charting optical density (ordinate) against distance migrated (abscissa) on graph paper. The protein distribution was measured by cutting the charted electrophoretic curve into its various protein components, weighing each component, and relating the weight to the total weight of all components. ${ }^{3}$ The elec-

3 No corrections were made for the variation in dyebinding capacity of the different proteins (9). 
TABLE I

Constancy of excretion of hexosamine in the urine

\begin{tabular}{|c|c|c|c|c|c|}
\hline Diagnosis & $\begin{array}{l}\text { No. } \\
\text { obs. }\end{array}$ & Observation & Mean & $V^{*}$ & Range \\
\hline $\begin{array}{l}\text { Scleroderma } \\
\text { (27 yr. \%) }\end{array}$ & $\begin{array}{l}74 \\
31 \\
63\end{array}$ & $\begin{array}{l}24 \text { hr. urine volume }(m l .) \\
\text { Hexosamine (mg./24 hr.) } \\
\text { Creatinine (mg./24 hr.) }\end{array}$ & $\begin{array}{c}1,480 \\
76.5 \\
841\end{array}$ & $\begin{array}{l} \pm 18 \\
\pm 9 \\
\pm 10\end{array}$ & $\begin{array}{c}750-2,000 \\
65-88 \\
558-1,007\end{array}$ \\
\hline $\begin{array}{l}\text { Ankylosing spondylitis } \\
\text { (40 yr. \%) }\end{array}$ & 7 & $\begin{array}{l}24 \text { hr. urine volume }(m l .) \\
\text { Hexosamine (mg./24 } \mathrm{hr} .)\end{array}$ & $\begin{array}{r}1,600 \\
91.7\end{array}$ & $\begin{array}{l} \pm 34 \\
\pm 5\end{array}$ & $\begin{array}{l}740-2,050 \\
85-99\end{array}$ \\
\hline $\begin{array}{l}\text { Myxedema } \\
\text { (54 yr. \%) }\end{array}$ & $\begin{array}{l}60 \\
28\end{array}$ & $\begin{array}{l}24 \text { hr. urine volume (ml.) } \\
\text { Hexosamine (mg./24 } \mathrm{kr} .)\end{array}$ & $\begin{array}{r}1,940 \\
51.4\end{array}$ & $\begin{array}{l} \pm 15 \\
\pm 9\end{array}$ & $\begin{array}{c}1,000-2,340 \\
42-60\end{array}$ \\
\hline
\end{tabular}

trophoretic distribution of hexosamines was determined by cutting the paper according to the known protein bands. Each band of paper was then hydrolyzed in 3 ml. of $1 \mathrm{~N}$ hydrochloric acid for 15 hours and after isolation on Dowex-50, the hexosamine contents were determined (5).

\section{RESULTS}

\section{Constancy of hexosamine excretion}

Six normal adult men and four women were found to excrete approximately the same daily amounts of hexosamine in the urine $(84 \mathrm{mg}$. per 24 hours), with moderate variations ( $\pm 12 \mathrm{mg}$. per 24 hours) from person to person. Values above 100 and below $65 \mathrm{mg}$. per 24 hours were beyond the observed normal range. The daily rate of excretion, however, in the same subject was more constant (Table I). One patient with scleroderma was studied for a period of three months during which time urine volume, hexosamine and creatinine determinations were made. Using the coefficient of variation $(\mathrm{V})$ to compare the variability of these different observations, it can be seen that the excretion of hexosamine was as constant as the excretion of creatinine, despite wide variations in urine volume. A low degree of variability in the excretion of hexosamine was also observed in a patient with rheumatoid arthritis studied for seven consecutive days and in a patient with myxedema studied for two months. There was no apparent influence of the menstrual cycle on the excretion of hexosamine in the urine of two women with scleroderma who had normal cycles and whose daily urine collections had been analyzed for three months.

The hourly excretion rate of hexosamine in the urine was studied in one patient with scleroderma and found to be fairly constant, despite wide variations in the rate of urine formation (Table II). A reduction in hexosamine excretion during the hours from 8:00 P.M. to midnight was observed on two consecutive days.

\section{Urine hexosamine in chronic diseases}

Urinary hexosamine excretion was first studied in normal individuals and later in patients with a variety of chronic diseases in order to assess normal and abnormal excretion limits (Table III). All of the urine specimens represented 24-hour collections during periods when no medication was being administered, with the exception of a few patients with rheumatoid arthritis who were being

TABLE II

Rate of excretion of hexosamine in urine of patient with scleroderma

\begin{tabular}{|c|c|c|c|}
\hline Day & Collection period & $\begin{array}{c}\text { Urine } \\
\text { volume } \\
\text { (ml./hr.) }\end{array}$ & $\begin{array}{c}\text { Hexosamine } \\
(\text { mg./hr.) }\end{array}$ \\
\hline 1 & $\begin{array}{l}8 \text { A.M.-12 N. } \\
\text { 12 N.-4 P.M. } \\
4 \text { P.M.-8 P.M. } \\
8 \text { P.M.-12 M. } \\
12 \text { M.-8 A.M. }\end{array}$ & $\begin{array}{r}144 \\
80 \\
84 \\
12 \\
39\end{array}$ & $\begin{array}{l}3.5 \\
3.5 \\
3.5 \\
1.2 \\
2.5\end{array}$ \\
\hline 2 & $\begin{array}{l}8 \text { A.M. }-12 \text { N. } \\
\text { 12 N.-4 P.M. } \\
4 \text { P.M.-8 P.M. } \\
8 \text { P.M.-12 M. } \\
12 \text { M.-8 A.M. }\end{array}$ & $\begin{array}{r}139 \\
59 \\
54 \\
38 \\
72\end{array}$ & $\begin{array}{l}3.2 \\
4.0 \\
3.8 \\
2.5 \\
3.9\end{array}$ \\
\hline 3 & 8 A.M. -8 A.M. & 95 & 3.5 \\
\hline 4 & 8 A.M.-8 A.M. & 77 & 3.0 \\
\hline 5 & 8 A.M. -8 A.M. & 24 & 3.4 \\
\hline 6 & 8 A.M. -8 A.M. & 36 & 3.7 \\
\hline
\end{tabular}


TABLE III

Levels of urinary excretion of hexosamine in a variety of clinical diseases

\begin{tabular}{lcc}
\hline \hline \multicolumn{1}{c}{ Diagnosis } & No. & $\begin{array}{c}\text { Hexosamine } \\
(\mathbf{m g} . / 24 \mathrm{hrs} .)\end{array}$ \\
\hline Metastatic carcinoma of colon & 1 & 76 \\
Scleroderma & 3 & $82 \pm 5^{*}$ \\
Rheumatoid arthritis & 9 & $94 \pm 15$ \\
Islet cell tumor of pancreas & 1 & 104 \\
Portal cirrhosis & 1 & 112 \\
Metastatic carcinoma of rectum & 1 & 123 \\
Metastatic carcinoma of breast & 1 & 126 \\
Pancreatitis with obstructive jaundice & 1 & 137 \\
Acute hepatitis with jaundice & 1 & 142 \\
Normal adults & 10 & $84 \pm 12$ \\
& &
\end{tabular}

* Standard deviation.

treated with salicylates. The excretion of hexosamine was increased in many instances without any apparent relationship to the specific nature of the illness: In some illnesses it was relatively unaffected. Only two of nine patients with active rheumatoid arthritis excreted more than $100 \mathrm{mg}$. per 24 hours.

\section{Serum and urine hexosamine in acute clinical stress}

In order to study some of the physiological factors related to the increased urinary excretion and elevated serum hexosamine levels observed in chronic diseases, cases of acute spontaneous and induced clinical stress were studied. Some of the responses of serum hexosamine levels to acute stress are shown in Figure 1.

Myocardial infarction: Two cases of acute myocardial infarction each demonstrated an abrupt increase in the serum hexosamine levels from assumed normal levels, which gradually returned toward normal again after one to two weeks.

Epinephrine administration: In an attempt to induce a stress response, two normal men were given large doses of epinephrine, each receiving $2.2 \mathrm{mg}$. subcutaneously, daily in divided doses for five days. Despite evidence of epinephrine effect (nervousness, tachycardia, etc.) the serum hexosamine levels were not significantly altered.

Surgical operations: The serum hexosamine levels were studied in three normal adult female patients who were operated upon for gynecological conditions: A. T. had a multiple myomectomy for uterine fibroids, P. W. had an hysterectomy and right salpingo-oophorectomy for uterine fibroids, and S. M. had an ovariectomy for an ovarian cyst. All developed sharp increases in serum hexosamine levels, reaching their peaks at approximately one week after operation.

The excretion of urine hexosamine was also studied in cases of acute surgically-induced stress
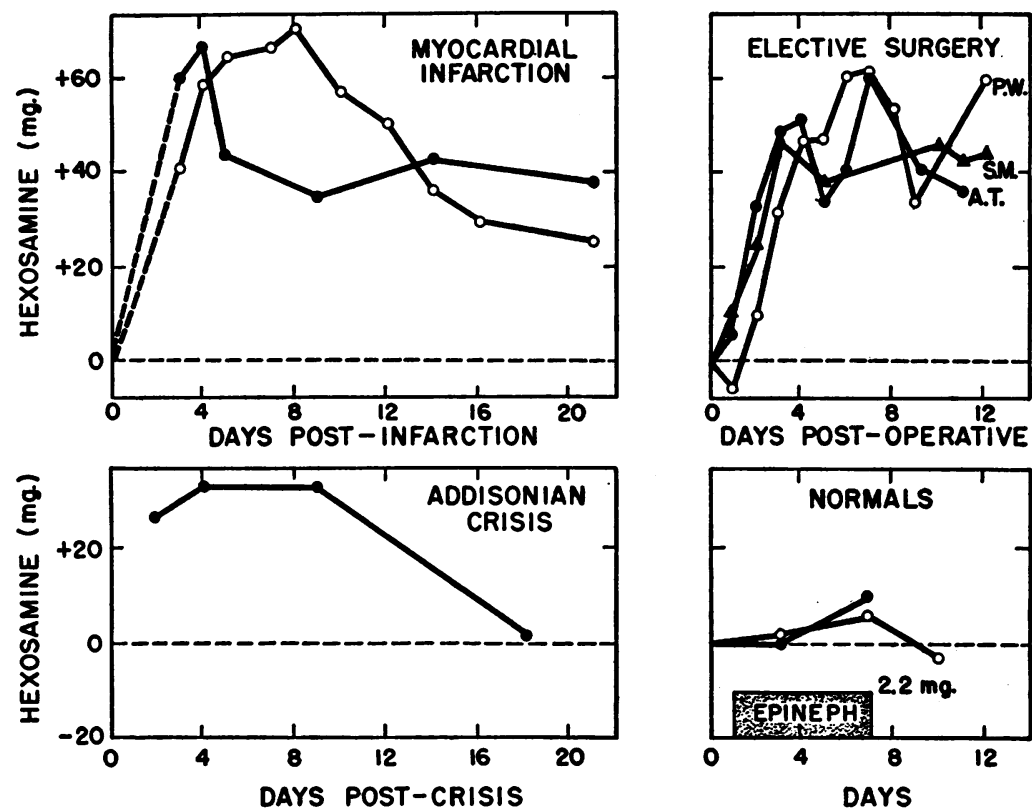

Fig. 1. Eftect of Acute Clinical Diseases, Operations, and TreatMent with Epinephrine on the LeVtes of Hexosayine in the Seruy 


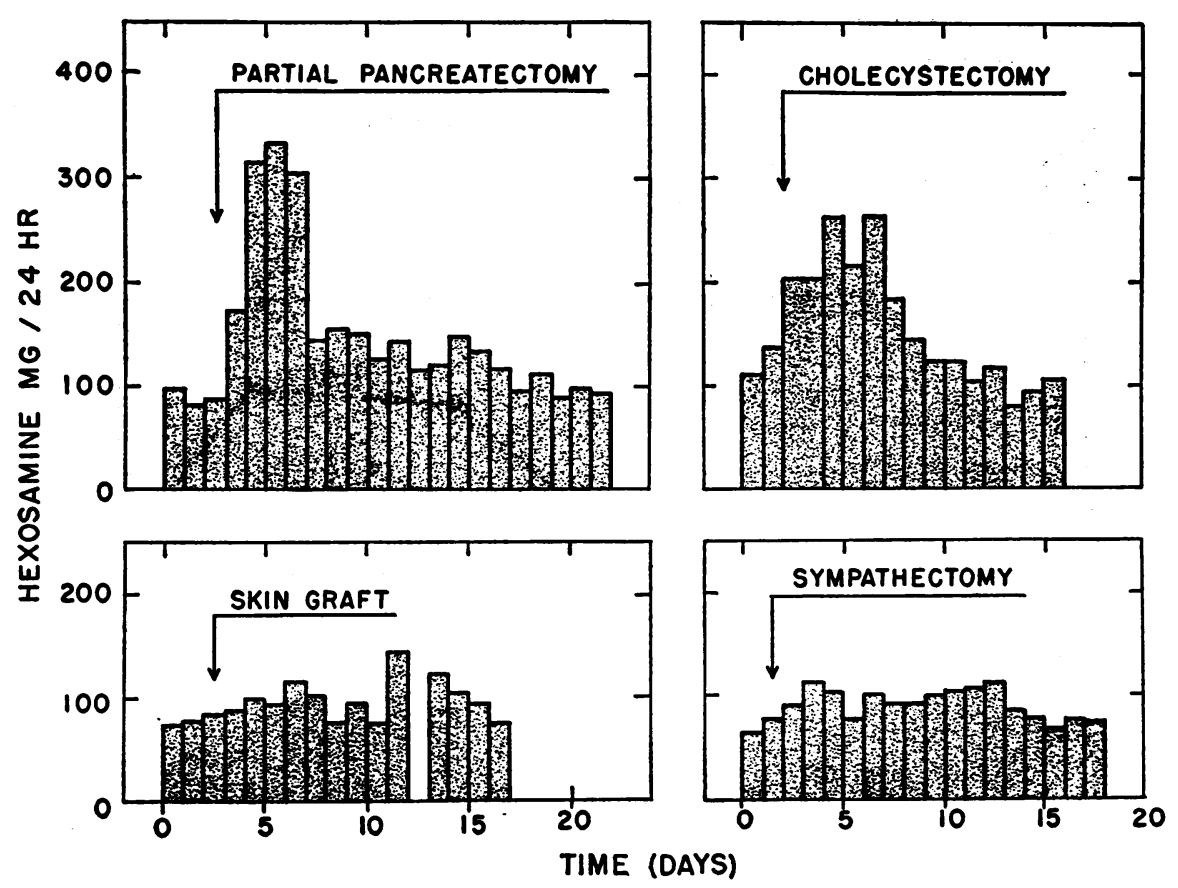

Fig. 2. Effect of Surgical Operations on the Excretion of Hexosamine IN THE URINE

(Figure 2). The patients consisted of a 25-year old man who had surgical removal of an islet cell tumor of the pancreas, a 55-year old man with obstructive jaundice due to pancreatitis on whom a cholecystectomy and drainage of the common bile duct were performed, a 43-year old woman who had a skin graft on the site of a previous radical mastectomy scar, and a 24-year old woman with scleroderma who had a lumbodorsal sympathectomy. All demonstrated increased excretion of urine hexosamine exceeding the observed normal range, rising in one case to $300 \mathrm{mg}$. per 24 hours (pancreatectomy), and returning to normal in two to three weeks in all patients.

Acute gouty arthritis: A 46-year old man, while under observation for another study, developed a spontaneous attack of gout with marked involvement of the big toe, ankle and knee of the same leg (Figure 3). This attack was followed by an increase in serum hexosamine which occurred simultaneously with increased excretion of urinary hexosamine and an acceleration of the blood sedimentation rate. Analysis of the electrophoretically separated serum proteins demonstrated that the increase in serum hexosamine was almost entirely confined to the hexosamine in the alpha globulin fractions. No statistically significant changes in the relative amounts of the serum protein fractions were detectable. The attack of gout subsided after 10 days and was followed by a return toward normal of the plasma and urine hexosamine.

\section{Influence of adrenal cortex on serum and urine hexosamine}

Since the adrenal glands become physiologically hyperactive following acute injury or stress, and since serum levels and urinary excretion of hexosamine increased following stress, the role of the adrenal cortex as a mediator in this response was considered.

To study serum hexosamine changes in the absence of normal adrenocortical function, a 17year old boy with known Addison's disease was observed. He entered the hospital in acute Addisonian crisis with a temperature of $104^{\circ}$, due to infectious mononucleosis. His serum hexosamine levels had been normal prior to this admission but became transiently elevated with this acute illness (Figure 1). The patient died several weeks later 


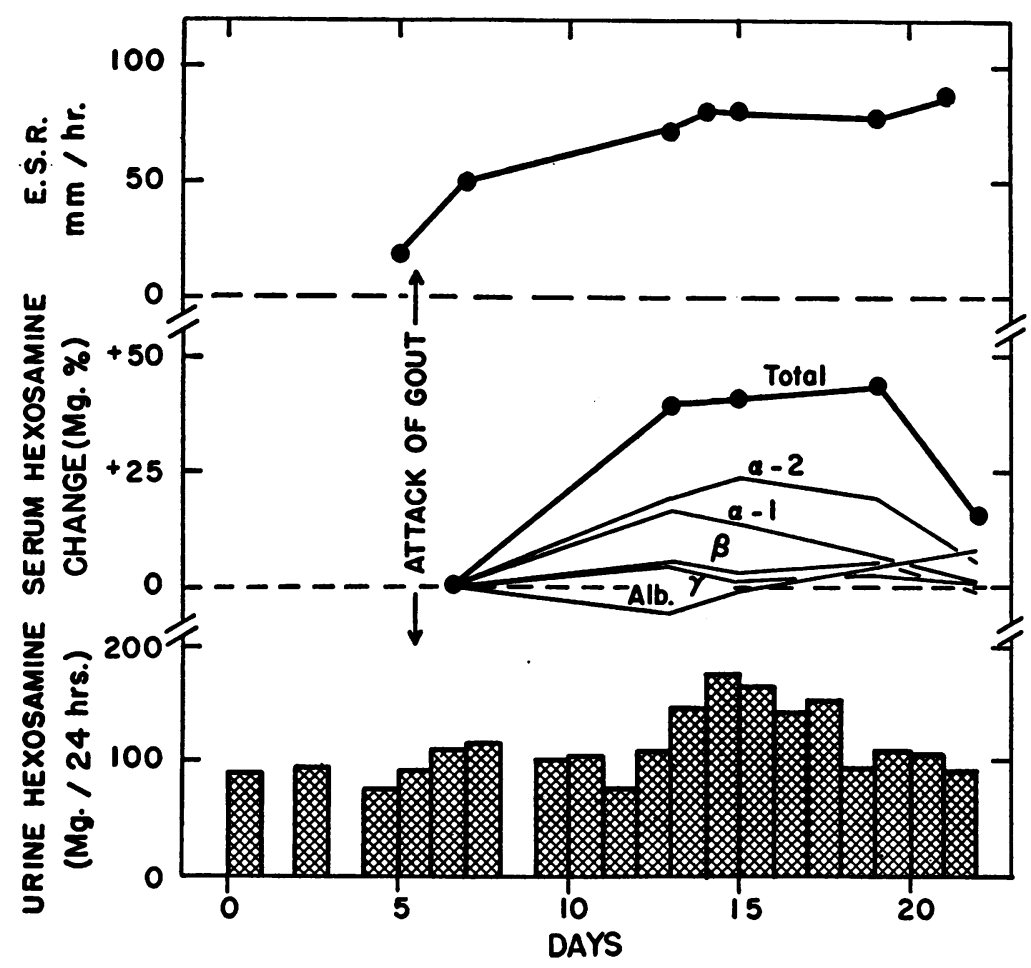

Fig. 3. Efrect of an Acute Attack of Gouty Arthritis on the Distribution of Hexosamine in the Serum, and the Excretron or HeXOSAMINE IN THE URINE
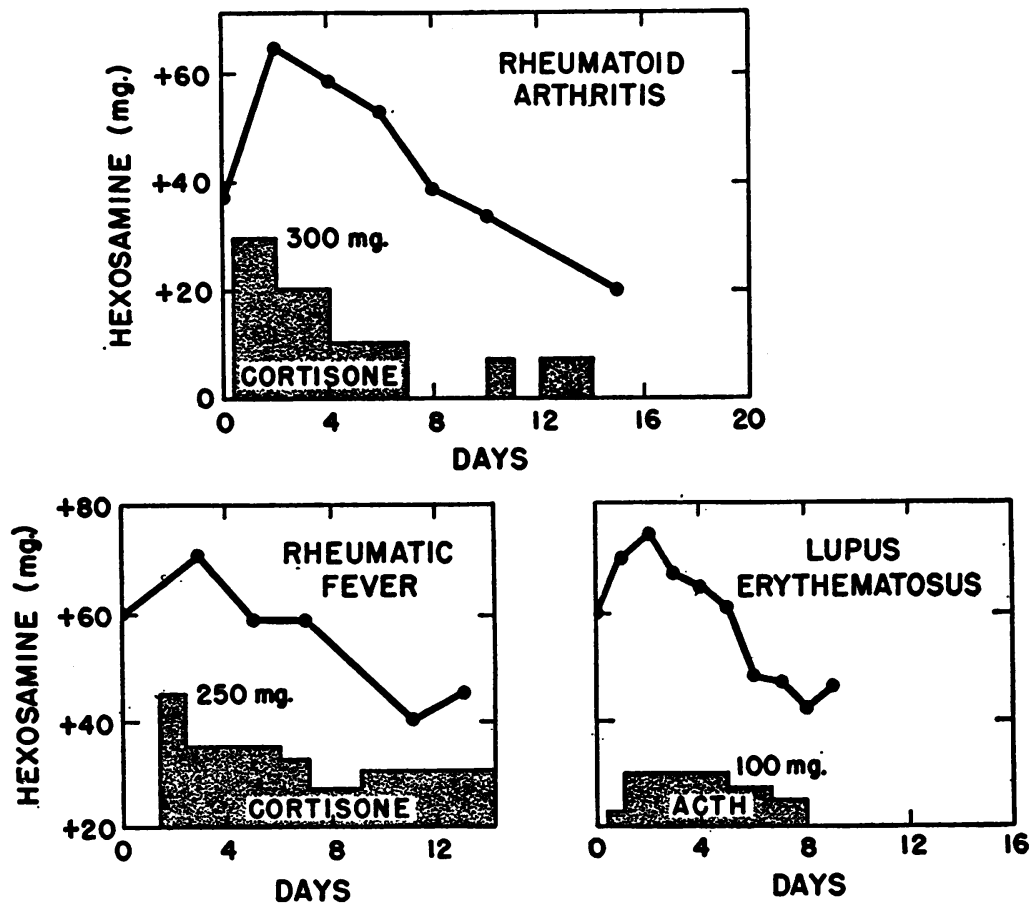

Fig. 4. Response of Elevated Serum Hexosamine Levels to Treatment with Corticotropin (ACTH) and Cortisone 
TABLE IV

Effect of corticotropin on excretion of hexosamine in the urine

\begin{tabular}{cccc}
\hline \hline & $\begin{array}{c}\text { Cortico- } \\
\text { tropin } \\
\text { (units) }\end{array}$ & \multicolumn{2}{c}{$\begin{array}{c}\text { Urine herosamine } \\
\text { (ms./24 hrs.) }\end{array}$} \\
\cline { 3 - 4 } & & L. B. & N. K. \\
\hline 1 & & 82 & 152 \\
2 & 100 & 90 & 152 \\
3 & 100 & 76 & 135 \\
4 & 100 & 96 & 136 \\
5 & & 72 & 141 \\
6 & & 77 & 121 \\
7 & & 98 & 122 \\
8 & & 86 & 131 \\
9 & & 90 & 125 \\
\hline
\end{tabular}

as a result of another infection, and at autopsy, there was no evidence of any adrenal cortical tissue present. Four other patients with well-controlled Addison's disease had normal serum hexosamine levels.

To study the effect of adrenal cortical hormones, patients with abnormally elevated serum hexosamine levels were treated with corticotropin or cortisone. Examples in patients with rheumatic fever, rheumatoid arthritis, and lupus erythematosus are shown in Figure 4. In each instance, hormonal treatment resulted in a transient increase in hexosamine levels followed by a return toward normal, while the hormone was still being given. This is contrary to what one would expect if the adrenal cortex had produced an hexosamine-increasing factor. One normal individual and four patients with hyperthyroidism who had normal hexosamine levels before treatment received corticotropin (100 mg." per day for 5 to 10 days) and no changes in hexosamine levels resulted.

The effect of ACTH on the urinary excretion of hexosamine was also studied (Table IV) in two patients each of whom received 100 units of corticotropin daily intramuscularly in divided doses for three days. Patient L. B. was a 45-year old woman with inactive rheumatoid arthritis who was excreting normal amounts of hexosamine. This excretion rate was uninfluenced by corticotropin. The other patient, N. K., a 16-year old boy who was recovering from a leg operation, had an increased rate of excretion of hexosamine before treatment with corticotropin. The urinary

4 Since these experiments were conducted prior to the unit standardization of ACTH, the dosage is expressed in milligrams. excretion of hexosamine did not increase further during treatment with corticotropin, but actually appeared to decrease. This is contrary to what one would expect if the adrenal cortex were responsible for the stress induced hexosamine response.

\section{DISCUSSION}

Serum hexosamine levels have been reported to be elevated in many unrelated chronic diseases such as leukemia, Hodgkin's disease, carcinomatosis, periarteritis nodosa, rheumatic fever, rheumatoid arthritis, disseminated lupus erythematosus and chronic infections $(1,2,10)$. Serum hexosamine levels have also been found to be elevated following acute diseases such as pneumonia, myocardial infarction (1) and experimental injury to animals $(3,4,11)$.

The data presented here confirm the observations of West and Clarke (1) on myocardial infarction but demonstrate further that other types of unrelated acute diseases and injuries to the body can also induce an increase in serum hexosamine. In one instance (case of gout) the increase in serum hexosamine was found to be in the hexosamines contained in the alpha-globulin fractions. This is consistent with observations that the alphaglobulins (12) and hexosamine-rich alpha-globulin mucoproteins $(13,14)$ increase in response to other acute injuries or diseases such as burns (12) and pneumonia $(13,14)$.

Glucosamine has been identified as an important component of urinary mucus $(15,16)$, a carbohydrate-rich material long recognized as a normal constituent of urine $(15,17)$. A chemical characterization of most of the glucosamine-containing substances in the urine, however, has not been made. It has recently been shown that approximately $\mathbf{4 0}$ per cent of the total urine hexosamine is contained in low molecular weight freely dialyzable substances, and that almost all of the nondialyzable urine hexosamine was found to migrate electrophoretically at $\mathrm{pH} 8.6$ as a single mucoprotein peak (18) which may be similar in part to the urine mucoprotein isolated by Tamm and Horsfall (19).

It was observed that following acute diseases or body injury, the increased excretion of urine hexosamine coincided in time with the increase seen in serum hexosamine levels. Until the hexosa- 
mine-containing substances in serum and urine are more clearly identified, however, their physiological relationship cannot be established.

The increase in serum hexosamine levels and in the urinary excretion of hexosamine following acute diseases or injury does not appear to be mediated by the adrenal cortex for the following reasons: 1) A patient with Addison's disease developed a typical increase in serum hexosamine during a crisis, 2) corticotropin or cortisone administration was followed by a reduction in the abnormally elevated hexosamine levels in urine and serum, but had no effect when the urine and serum levels were normal at the start of treatment, 3) plasma hexosamine levels increased following surgical stress in adrenalectomized rats (20). The neural or humoral factors responsible for the observed changes in serum and urinary hexosamine following stress are as yet unidentified.

\section{SUMMARY}

Serum hexosamine levels increase in response to a variety of acute clinical conditions. This increase was demonstrated following myocardial infarctions, surgical operations, and an acute attack of gout. In the case of gout an increase in the alpha-globulin hexosamines was shown to account for the observed increase in total serum hexosamine.

Excretion of urine hexosamine increased following surgical operations (11) and following an attack of gout.

Corticotropin or cortisone administration was followed by a reduction in the abnormally elevated serum hexosamine levels in rheumatic fever, rheumatoid arthritis, and lupus erythematosus. Corticotropin had no significant effect in five subjects in whom the serum hexosamine levels were normal before treatment. A patient with Addison's disease was able to increase the serum hexosamine level in response to stress.

Corticotropin had no significant effect where the urinary hexosamine excretion was normal before treatment but appeared to diminish the excretion in a case in which the hexosamine had been increased.

The stress-hexosamine response in the serum and urine does not appear to be mediated by the adrenal cortex.

\section{ACKNOWLEDGMENTS}

We are very grateful to Dr. Louis J. Soffer for his kind permission to use serum hexosamine data obtained from the Medical Services of the Mt. Sinai Hospital, N. Y.

We wish to thank Dr. Robert R. Smith of the National Cancer Institute for making available clinical material for the surgical stress studies, Dr. John L. Fahey for supplying urine specimens from cases of malignancy, and Mrs. Anne B. Elden for performing the creatinine determinations.

\section{REFERENCES}

1. West, R., and Clarke, D. H., The concentration of glucosamine in normal and pathological sera. J. Clin. Invest., 1938, 17, 173.

2. Boas, N. F., and Soffer, L. J., The effect of adrenocorticotropic hormone and cortisone on the serum hexosamine level in acute disseminated lupus erythematosus. J. Clin. Endocrinol., 1951, 11, 39.

3. Schlamowitz, S. T., DeGraff, A. C., and Schubert, M., Studies of tissue response to injections of enzymes. II. Changes in rabbit plasma and tissue hexosamine induced by a single subcutaneous injection of trypsin. Circulation, 1950, 1, 822.

4. Boas, N. F., and Peterman, A. F., Effects of age, food intake, and stress on plasma hexosamine levels in the rat. Proc. Soc. Exper. Biol. \& Med., 1953, 82, 19.

5. Boas, N. F., Method for the determination of hexosamines in tissues. J. Biol. Chem., 1953, 204, 553.

6. Videbaek, A. A., Asboe-Hansen, G., Astrup, P. Faber, V., Hamburger, CHR., Schmith, K. Sprechler, M., and Brфchner-Mortensen, K., Effect of ACTH and cortisone on rheumatic fever. Acta endocrinol., 1950, 4, 245.

7. Astrup, P., and Grüner, A., Urinary excretion of hexosamines and glucuronic acid during treatment with ACTH. Scandinav. J. Clin. \& Lab. Invest., 1951, 3, 197.

8. Durrum, E. L., A microelectrophoretic and microionophoretic technique. J. Am. Chem. Soc., 1950, 72, 2943.

9. Kunkel, H. G., and Tiselius, A., Electrophoresis of proteins on filter paper. J. Gen. Physiol., 1951, 35, 89.

10. Rosenberg, C., and Schloss, B., Plasma hexosamine levels in acute rheumatic fever. Am. Heart J., 1949, 38, 872.

11. Werner, I., On regeneration of serum polysaccharide and serum proteins in normal and intoxicated rabbits. Acta physiol. Scandinav., 1949, 19, 27.

12. Gjessing, E. C., and Chanutin, A., An electrophoretic study of plasma and plasma fractions of normal and injured rats. J. Biol. Chem., 1947, 169, 657.

13. Winzler, R. J., and Smyth, I. M., Studies on the mucoproteins of human plasma. II. Plasma muco- 
protein levels in cancer patients. J. Clin. Invest., 1948, 27, 617.

14. Mehl, J. W., Humphrey, J., and Winzler, R. J., Mucoproteins of human plasma. III. Electrophoretic studies of mucoproteins from perchloric acid filtrates of plasma. Proc. Soc. Exper. Biol. \& Med., 1949, 72, 106.

15. Sahlstedt, A. V., Die Schleimsubstanz des Pferdeharns. Scandinav. Arch. f. Physiol., 1916, 33, 183.

16. Kobayasi, T., Biochemical studies on carbohydrates. LV. Urine mucoid. J. Bioch. (Japan), 1939, 30, 451.
17. Mörner, K. A. H., Untersuchungen über die Proteinstoffe und die eiweissfällendere Substanzen des normalen Menschenharns. Skandinav. Arch. $f$. Physiol., 1895, 6, 332.

18. Boas, N. F., and Foley, J. F., In preparation.

19. Tamm, I., and Horsfall, F. L., Jr., A mucoprotein derived from human urine which reacts with influenza, mumps, and Newcastle disease viruses. J. Exper. Med., 1952, 95, 71.

20. Boas, N. F., and Foley, J. F., Effect of thyroidectomy and hypophysectomy on plasma hexosamine levels in the rat. Endocrinology, 1955, 56, 306. 